\title{
Novel Insights into Genetic Approaches in Glioblastoma Multiforme Therapy
}

\author{
Abdul Rahman I. Ghani ${ }^{1,2}$, Esam Bashir Yahya ${ }^{3, *}$, Abdulmutalib Alabeed Allaq $^{4}$, Atty Sofea Abdul Khalil ${ }^{5}$
}

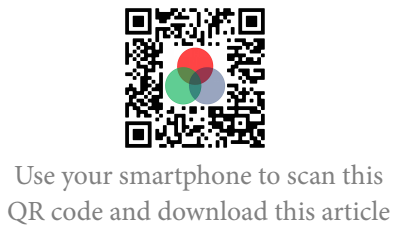

${ }^{1}$ Department of Neurosciences, School of Medical Sciences, Universiti Sains Malaysia, Kubang Kerian, Kelantan 16150, Malaysia

${ }^{2}$ Department of Neurosciences, Hospital Universiti Sains Malaysia, Kubang Kerian, Kelantan 16150, Malaysia

${ }^{3}$ School of Industrial Technology, Universiti Sains Malaysia, Penang 11800, Malaysia

${ }^{4}$ Faculty of applied science, Universiti Teknologi MARA, Shah Alam, Malaysia

${ }^{5}$ Hospital Seberang Jaya, Jalan Tun Hussein Onn, Seberang Jaya, Permatang Pauh, 13700, Penang, Malaysia

\section{Correspondence}

Esam Bashir Yahya, School of Industrial Technology, Universiti Sains Malaysia, Penang 11800, Malaysia

Email: essam912013@gmail.com

History

- Received: Nov 02, 2021

- Accepted: Jan 06, 2022

- Published: Jan 29, 2022

DOI : 10.15419/bmrat.v9i1.722

\section{Check for updates}

\section{Copyright}

(-) Biomedpress. This is an openaccess article distributed under the terms of the Creative Commons Attribution 4.0 International license.

\begin{abstract}
Glioblastoma multiforme is one of the most common and malignant types of central nervous system (CNS) tumors. Despite the great advances in treatment modalities and the variety of therapeutic options, it remains largely incurable with continuously growth incidence, due to the genomic instability of glioblastoma multiforme cells, their heterogeneity, and their resistance to chemo- and radiotherapies. The aggressive behavior of these brain tumors and their sequestered location behind the blood-brain barrier restricts the role of the immune system. Great success has been made recently in glioblastoma multiforme treatment using genetic based approaches to selectively target cancerous cells and restore tumor suppressor gene expression or silence specific oncogenes to prevent their expression. The use of genetic approaches has attracted more interest and research and has revealed their ability to regulate the expression of glioblastoma multiforme oncogenes without changing the genotype and thus avoiding possible genotoxicity. This review delivers an overview of glioblastoma multiforme cell biology, tumorigenesis, and immune surveillance, and discusses recent advances in genetic based therapies of glioblastoma multiforme.
\end{abstract}

Key words: glioblastoma multiforme, cancer cell biology, gene therapy, brain tumors, oncogenes

\section{INTRODUCTION}

Glioma is a general term that refers to brain tumors that have been classified based on their presumed cell of origin: astrocytic tumors (including astrocytoma, anaplastic astrocytoma, and glioblastoma), ependymomas, oligodendrogliomas, and mixed gliomas ${ }^{1}$. Glioblastoma multiforme is considered the most frequently occurring and malignant primary astrocytoma, accounting for more than $60 \%$ of all adult brain tumors and approximately 17,000 new diagnoses each year $^{2}$. Despite the great advances and the variety of modern therapies against glioblastoma multiforme, it is still considered one of the deadliest cancers and is characterized by an extremely poor prognosis ${ }^{3}$. Its features include high aggressiveness, tremendous invasive capacity, and resistance to conventional therapeutic approaches such as chemo- and radiotherapy ${ }^{4}$. Gliomas have been classified by the World Health Organization (WHO) according to their level of malignancy into grades I to IV: grade I gliomas include mild lesions that are characterized by low proliferative potential, while grades II to IV are highly invasive and malignant. Glioblastoma multiforme is designated grade IV-the most aggressive, invasive, and undifferentiated type of CNS tumor ${ }^{5}$. Mounting knowledge of the properties and characteristics of glioblastoma multiforme, being the most aggressive and located in very sensitive part of the body, have sparked the recent application of advanced gene-based therapies to target the cancer's molecular mechanisms.

Gene therapy has been defined by many authors as the introduction, alteration, or removal of certain nucleic acids-such as genes, oligonucleotides, gene segments, microRNAs (miRNAs), or small interfering RNA (siRNA) - from targeted cells, leading to altered gene expression and/or the synthesis of an exogenous protein ${ }^{6,7}$. A variety of gene therapy approaches have been developed and tested for use in glioblastoma multiforme therapy, especially in advanced cases; many of these approaches show promising potential and provide hope for a new generation of molecular therapies. The first attempt at using gene therapy to treat glioblastoma was published in 1996 and involved the use of a viral vector for $H S V$-TK gene delivery to the patient ${ }^{8}$. Since then, various viral and non-viral vectors have been used to deliver the genes to glioblastoma tumors ${ }^{9}$. Epigenetics is considered a marker of human cancers and represents any mitotically heritable alteration in gene expression apart from alteration of the DNA sequence (mutations) ${ }^{10,11}$. In the present review, we comprehensively discuss the natural biology, metastasis, immune surveillance, and current therapeutic approaches to glioblastoma multiforme. We also critically evaluate 
the recent advances in genetic based therapies, including oncogene silencing, suicide gene therapy, targeting angiogenesis, immunization gene therapy, targeting tumor cell-derived exosomes, tumor gene repair, and whole-genome editing therapies.

\section{GLIOBLASTOMA MULTIFORME TUMORIGENESIS AND IMMUNE SURVEILLANCE}

The past few decades have produced significant advances in the understanding of the nature of cancer cell biology, especially for glioblastoma multiforme. The dominant oncogenes and tumor suppressor genes that control the respective activation, upregulation, or inhibition of cellular functions impart aberrant characteristics onto normal cells, leading to their transformation into malignant cells ${ }^{\mathbf{1 2}}$. Glioblastoma is classified as class IV, the most aggressive, invasive, and undifferentiated type of CNS tumor ${ }^{5}$. However, the manifest the disease was reported to be associated with cancer cells, in addition to conscript and corrupt resident, which recruited normal cells to serve as contributing members around the cancer cells ${ }^{\mathbf{1 3}}$. The tumor microenvironment was reported to play a critical role in cancer metastasis and malignancy; the interaction between neoplastic tumor cells and their surrounding stroma leads to chronic proliferation and formation of organ-like structures, which are known as tumors and typify most human cancers ${ }^{14,15}$. The multifactorial contributions of activated or recruited brain cells to glioblastoma multiforme may be performed by some or all of the factors presented in Figure 1, including evading growth suppressor mechanisms of cells, chronic proliferative signaling, angiogenesis, resisting cell death, activating invasion and metastasis, enabling replicative immortality, evading immune-mediated destruction, and reprogramming energy metabolism ${ }^{\mathbf{1 6}}$.

\section{Glioblastoma multiforme cell biology}

The most frequent locations for glioblastoma are the cerebral hemispheres; as reported by Nakada et al. ${ }^{\mathbf{1 8}}$ more than $95 \%$ of glioblastoma multiforme tumors arise in supratentorial regions and only a small percentage occur in the spinal cord, cerebellum, and brainstem. Transformation of a normal cell into a cancerous cell may occur due to exposure to a carcinogenic agent, resulting in cells gaining the properties of rapid proliferation and metastasis ${ }^{9,19}$. Many studies have focused on the metabolism of different cancer cells and have revealed that metabolic reprogramming is a unique hallmark of cancer cells ${ }^{20,21}$.
Stone \& Darlington ${ }^{22}$ identified a few genetic changes that occurred within a single cell that were able to increase its proliferation, motility, migration, extracellular matrix metabolism, and tissue penetration. Macroscopically, glioblastoma multiforme is highly heterogeneous, featuring multifocal necrosis, hemorrhage, and cystic and gelatinous areas ${ }^{1}$. The glioblastoma multiforme tumor develops in the white matter of the CNS and is usually represented by a single, large, irregularly shaped lesion that resembles an anaplastic astrocytoma ${ }^{23}$. Brain cancer stem cells share core biological characteristics with normal stem cells, such as self-renewing potential and maintenance of proliferation. In particular, glioblastoma multiforme contains a subpopulation of cancer stem cells with enhanced self-renewal ability ${ }^{24}$. This is the case in brain cancer stem cells that reside in the dentate gyrus of the hippocampus and perivascular niches within the subependymal ventricular zone ${ }^{25}$; these cells have been reported to give rise to extremely highly proliferative tumor cells compared with other types of cancer cells, constituting an intense tumorigenic bulk within the parenchymal cells of the healthy brain as shown in Figure $\mathbf{2}^{17}$. To date, it is unclear whether glioma stem cells originate from normal neural stem cells or from undifferentiated neural or glial cells transformed into glioma stem cells; in any case, glioma stem cells are considered the main drivers of neoplastic transformation ${ }^{26,27}$.

\section{Metastasis and immune surveillance of glioblastoma multiforme}

The genomic instability of glioblastoma cells, their heterogeneity, behavior, infiltrative capacity, and sequestered location were found to restrict the role of the immune system against the tumor cells. The immune cells are not able to reach the site of tumor due to the presence of the blood-brain barrier, which restricts their action ${ }^{28}$. Furthermore, glioblastoma cells are able to develop several mechanisms to evade immune surveillance, including the release of inflammasome-dependent cytokines and the direct or indirect release of other costimulatory molecules that shape an immunosuppressive tumor microenvironment during the progression of the cancers ${ }^{29,30}$. Formation of new capillaries and blood vessels around the growing tumor is known as angiogenesis and was reported to be vital process highly observed within glioblastoma multiforme tumors-from small and localized tumors to enlarging ones-allowing them to metastasize $^{31}$. The environment of distant metastatic 


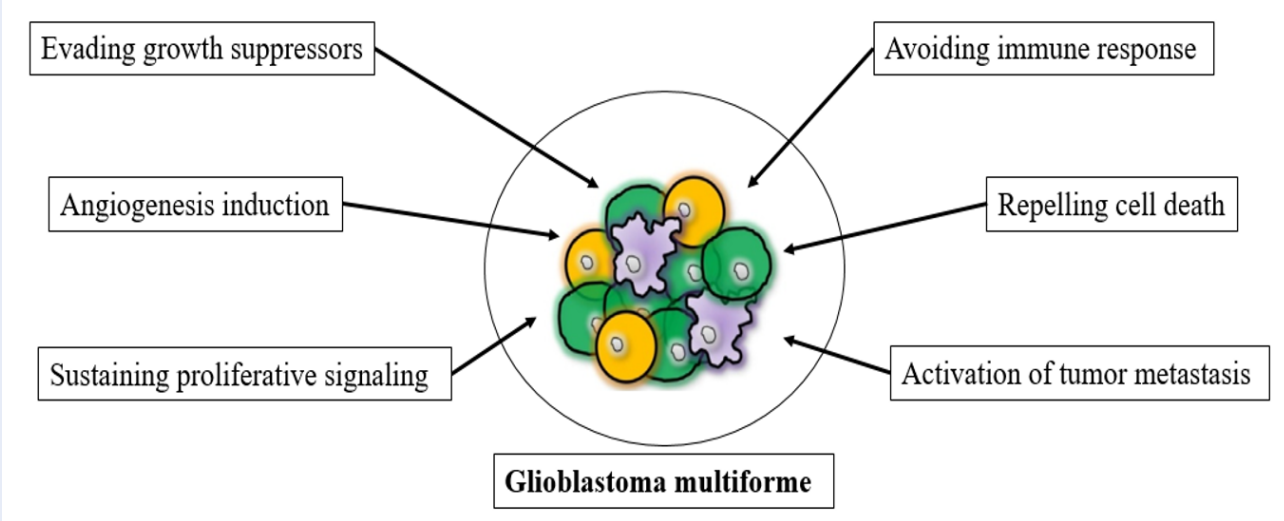

Figure 1: Illustration of multifactorial contributions of activated or recruited brain cells to Glioblastoma multiforme.

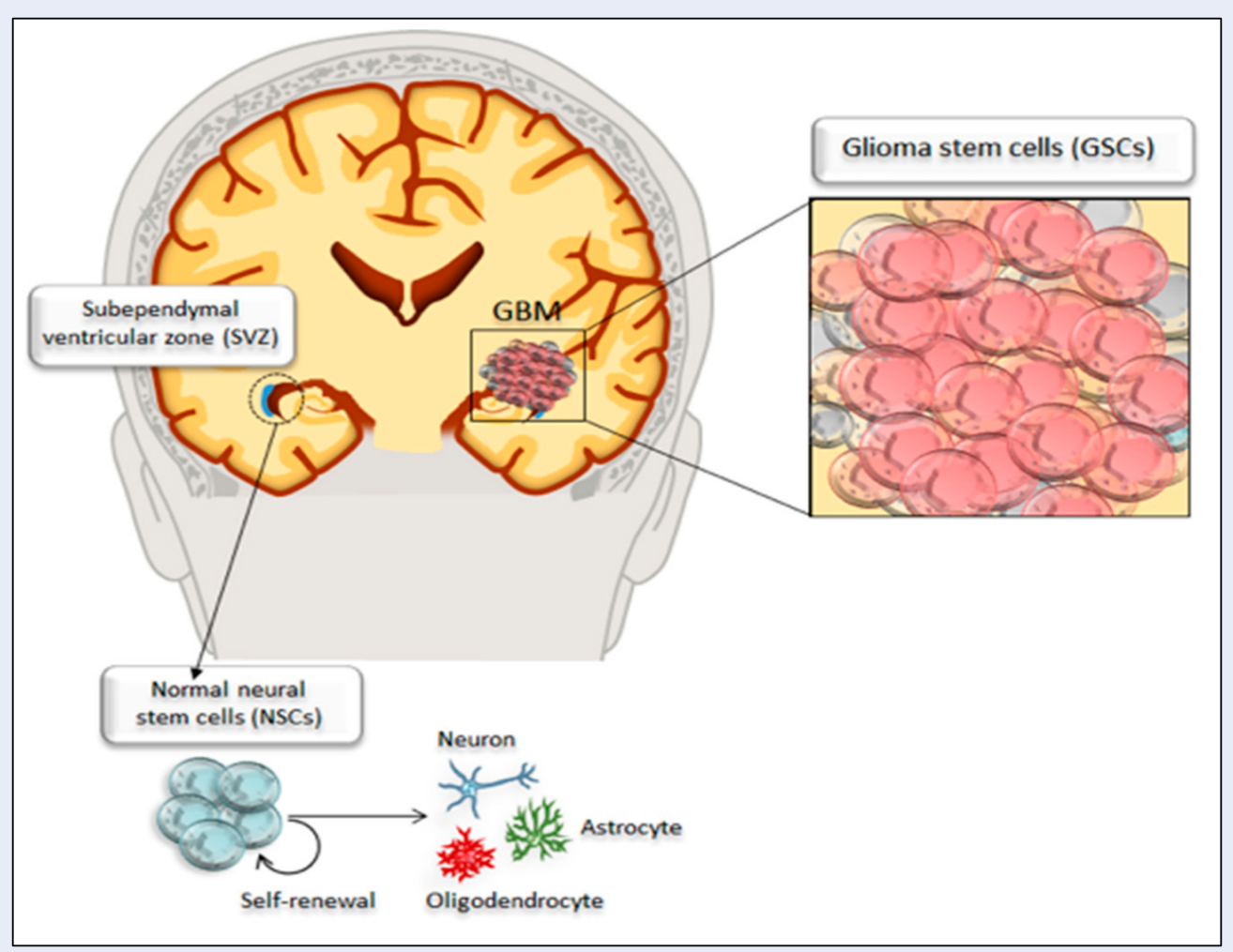

Figure 2: Schematic drawing of tumorigenesis of glioblastoma multiforme (GBM) from cancer stem cells in glioblastoma. Adapted from Ryskalin et al. ${ }^{17}$ 
target organs usually undergoes reprogramming to favor and enhance the growth and spread of the tumor ${ }^{32,33}$. Tumor cell invasion and migration (tumor metastasis) are key events in the metastatic cascade; Lambert et al. ${ }^{\mathbf{3 4}}$ studied different mechanisms of tumor metastasis and revealed that several cytokines are essential to this process, including IL-18 and IL- $1 \beta$, which are the two most widely studied mediators of cancer cell invasion and migration. These cytokines facilitate the invasion and spread of glioblastoma multiforme cells. Other investigations have reported that cancer cells may also circulate as dormant tumors and become clinically apparent within their lifetime ${ }^{35,36}$.

\section{Therapeutic approaches of glioblastoma multiforme}

The genetic instability of glioblastoma, its heterogeneity, behavior, infiltrative capacity, and sequestered location make it one of the most challenging cancers for conventional treatment techniques ${ }^{28}$. A variety of therapeutic approaches have been developed to treat glioblastoma multiforme and differ in terms of targeting either the tumor cells or enhancing the anti-cancer immune response; many factors influence the choice for the most suitable option in each cancer patient, which can be influenced by either tumor-associated factors or patient- and physician-associated factors. However, the ultimate goal of all treatments is to eradicate the glioblastoma multiforme cells, minimize the sequelae of treatment, preserve or restore form and function, and prevent any potential subsequent primary cancers ${ }^{37-39}$. Table 1 presents a summary of the current therapeutic options for glioblastoma multiforme. In this review, we will focus on the genetic and epigenetic approaches to treatment.

\section{Genetic based approaches for glioblastoma multiforme therapy}

Gene editing allows for selective targeting of cancerous cells by restoring tumor suppressor gene expression or silencing specific oncogenes and preventing their expression ${ }^{47}$. Most current gene therapy approaches aim at the altering, inserting, removing, or modulating particular genes instead of generalized, whole-genome editing ${ }^{48,49}$. Figure 3 presents the most common approaches of glioblastoma multiforme gene therapy discussed below.

\section{Oncogene silencing}

Oncogene silencing consists of the targeted delivery of a particular nucleic acid into tumor cells, which leads to downregulation of specific genes (silencing) ${ }^{\mathbf{5 0}}$. The extracellular matrix adhesion of glioblastoma multiforme cells is an important step for their invasion and many proteins have been investigated to play critical roles in accelerating this invasion ${ }^{51}$. The expression of these proteins has been reported to be extremely high in glioblastoma multiforme patients; therefore, silencing of oncogenes that express these proteins would inhibit the spread of glioblastoma multiforme cells $^{\mathbf{5 1 , 5 2}}$. RabGEF1 is a gene known for its oncogenic role in glioblastoma multiforme as a guaninenucleotide exchange factor for $R A B-5$. It has been reported that RabGEF1 is highly upregulated in human glioblastoma and other brain tumors ${ }^{53}$. Fan et al. ${ }^{54}$ evealed that downregulation of RabGEF1 inhibited glioblastoma cell proliferation and metastasis and induced autophagy of the cancer cells. GOLPH3 is an oncoprotein that has been reported to play a significant role in glioblastoma oncogenesis, and compelling evidence has demonstrated its role in the regulation of tumor cells as well as the migration and invasion of tumor cells under normal nutrient conditions ${ }^{55}$. In a recent study, Luo et al. ${ }^{\mathbf{5 6}}$ silenced the expression of GOLPH3 and observed marked reduction in adhesion of glioblastoma cells. The authors reported that GOLPH3 significantly contributed to the adhesion of glioblastoma cells by regulating the lysosomal degradation of the protein integrin subunit beta 1 (ITGB1) under serum starvation, and its silencing led to a reduction in the adhesion of glioblastoma cells and the levels of ITGB1 protein. Zinc finger E-boxbinding homeobox 2 (ZEB2) is a protein-coding gene that plays a critical role in the transcriptional regulation of various cellular functions and is abnormally expressed in brain tumors such as glioblastoma multiforme ${ }^{\mathbf{5 7}}$. Safaee et al. ${ }^{\mathbf{5 8}}$ investigated the effect of silencing ZEB2 on the cell cycle, apoptosis, and cytotoxicity of different glioblastoma cell lines and revealed that the suppression of ZEB2 induced apoptosis in all tested cell lines. Furthermore, the authors observed cytotoxic effects and marked reduction in migration of glioblastoma cell lines, suggesting the promising potential of ZEB2 silencing for the treatment of glioblastoma multiforme. Targeting programmed death ligand-1 ( $P D-L 1)$ or programmed cell death protein $1(P D-1)$ is another revolutionary strategy that has been applied to glioblastoma multiforme treatment. Qiu et al. ${ }^{59}$ studied the role of $P D-L 1$ in glioblastoma multiforme patients and reported that it bound to the Ras oncoprotein in glioblastoma cells which altered gene expression and led to significant acceleration of cellular growth, migration, and invasion pathways. The same authors silenced $P D-L 1$ and 
Table 1: Summary of the advantages and disadvantages of glioblastoma multiforme therapeutic options

\begin{tabular}{|c|c|c|c|}
\hline Therapeutic option & Advantages & Disadvantages & Ref \\
\hline Surgery & $\begin{array}{l}\text { Straightforward and does } \\
\text { not require advanced } \\
\text { equipment's }\end{array}$ & $\begin{array}{l}\text { Very difficult to operate, cannot restrict } \\
\text { the cancer alone, unsuitable for advanced } \\
\text { tumors and must be combined with other } \\
\text { salvage therapy }\end{array}$ & 40 \\
\hline Chemotherapy & $\begin{array}{l}\text { Salvage therapy for } \\
\text { glioblastoma multiforme } \\
\text { after surgery }\end{array}$ & $\begin{array}{l}\text { Highly toxic to normal cells, glioblas- } \\
\text { toma cells are able to overtake chemo- } \\
\text { treatment without major damage }\end{array}$ & 41 \\
\hline Radiation therapy & $\begin{array}{l}\text { Salvage therapy to improve } \\
\text { treatment outcome and re- } \\
\text { duce its duration }\end{array}$ & $\begin{array}{l}\text { Not suitable for metastatic and advanced } \\
\text { glioblastoma, possibly increase the accu- } \\
\text { mulation of gadolinium in the brain and } \\
\text { radio resistance }\end{array}$ & 42 \\
\hline Virotherapy & $\begin{array}{l}\text { Selective cytotoxicity } \\
\text { to cancer cells, stimu- } \\
\text { late anti-tumor immune } \\
\text { responses }\end{array}$ & $\begin{array}{l}\text { Potential pathogenicity in some viruses, } \\
\text { blood brain barrier may limitate viral ac- } \\
\text { cessability to glioblastoma cells and the } \\
\text { potential resistance }\end{array}$ & 43 \\
\hline Immunotherapy & $\begin{array}{l}\text { Self-improving response, } \\
\text { induction of long-term } \\
\text { immunity to glioblastoma }\end{array}$ & $\begin{array}{l}\text { Developing of immunosuppressive envi- } \\
\text { ronment by glioblastoma cells to limitate } \\
\text { the immune action and potential of au- } \\
\text { toimmune induction }\end{array}$ & 44 \\
\hline Gene therapy & $\begin{array}{l}\text { Fast and limited dosage on- } \\
\text { set, highly specific to can- } \\
\text { cer gene and safe for nor- } \\
\text { mal genes }\end{array}$ & $\begin{array}{l}\text { Depending on the strategy; possible gene } \\
\text { alteration, which may lead to other de- } \\
\text { fects, still under developing and experi- } \\
\text { ments }\end{array}$ & 45 \\
\hline Epigenetic therapy & $\begin{array}{l}\text { Does not cause any gene al- } \\
\text { teration and selectively tar- } \\
\text { geted defected tissue }\end{array}$ & $\begin{array}{l}\text { Extremely expensive, and still under in- } \\
\text { vestigation }\end{array}$ & 46 \\
\hline
\end{tabular}

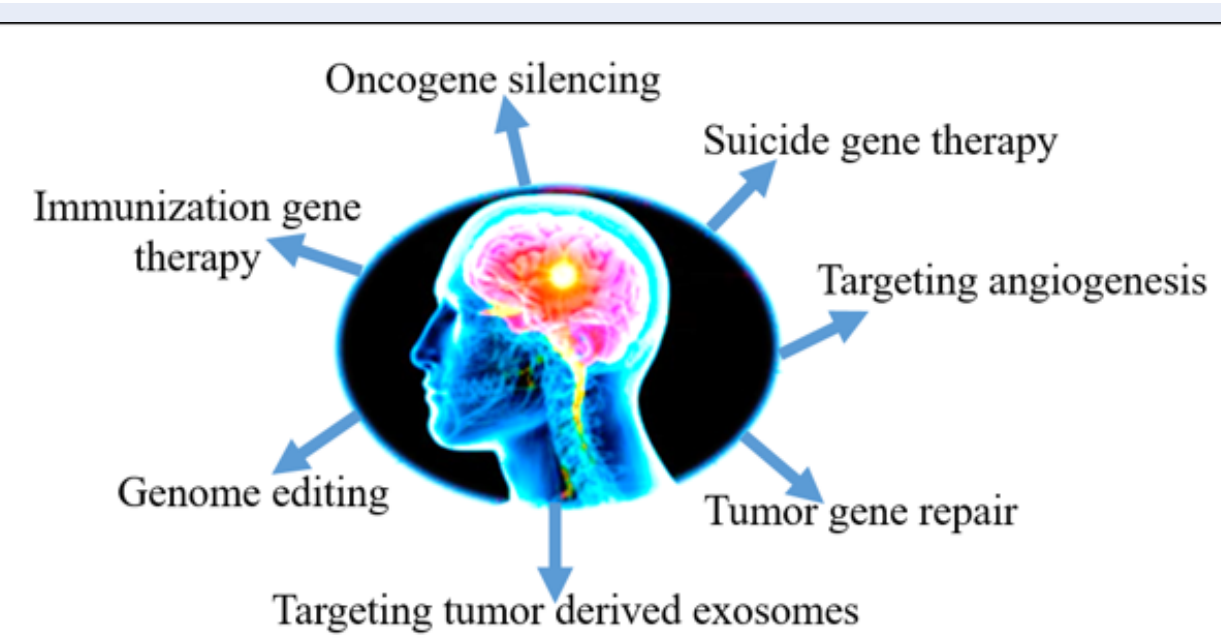

Figure 3: Major gene based strategies for glioblastoma multiforme treatment. 


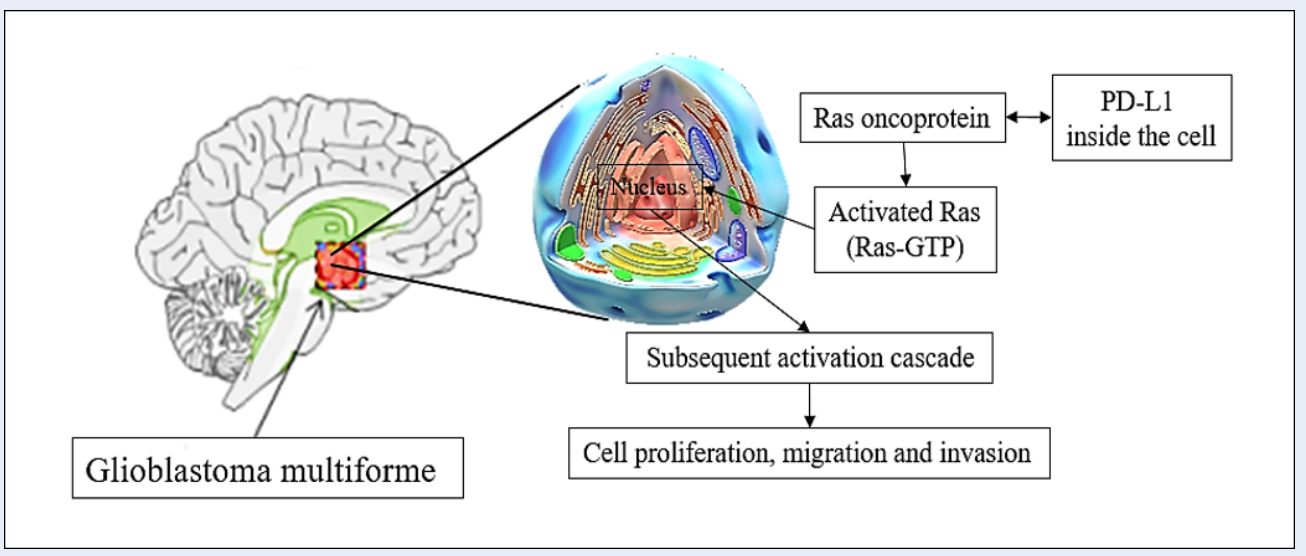

Figure 4: Illustration of PD-L1 gene role in the proliferation, migration and invasion of glioblastoma cells.

revealed that it played a vital role in glioblastoma multiforme cell proliferation and migration. The overexpression of $P D-L 1$ promoted glioblastoma multiforme cell development and invasion in rodents, while its silencing abolished them. Figure 4 presents a summary of the role of $P D-L 1$ in glioblastoma proliferation, migration, and invasion.

\section{Suicide gene therapy}

Suicide gene-based therapy consists of inserting genes that encode for cytotoxic proteins into glioblastoma cells either directly by inserting the toxin gene to reduce the viability of the cancer cells or indirectly by introducing a gene encoding an enzyme or protein with cytotoxic effects ${ }^{\mathbf{6 0}, 61}$. Different strategies for suicidal gene delivery have been evaluated; Li et al. ${ }^{62}$ developed a novel therapy for glioblastoma based on mesenchymal stem cells to counteract the aggressive spread and dissemination of the cancer. The authors genetically engineered the mesenchymal stem cells and integrated the suicide gene TGF- $\beta$ into their nuclei. Upregulation of TGF- $\beta$ was clearly observed in the patients' glioblastoma cells, in contrast to their non-neoplastic cortex cells, suggesting the high selectivity of this therapeutic approach. The same authors monitored the suicide gene products and demonstrated a significant improvement in the clinical efficacy, suggesting great potential for this approach in complicated brain cancers.

Gene therapy of glioblastoma with suicide genes using viral vectors has been also studied. The herpes simplex virus thymidine kinase (HSVtk) gene was inserted into glioblastoma cells using a viral vector; the expression of the gene led to the production of HSVtk protein, which phosphorylated and transformed the non-toxic prodrug ganciclovir into toxic ganciclovirtriphosphate ${ }^{63}$. Toxic ganciclovir-triphosphate produced from transfected cells was transported into neighboring cancer cells through gap junctions and led to a widespread and strong antitumor effect, even in cells that had not been genetically modified. Park et al. ${ }^{64}$ used the same method and combined the thymidine kinase gene with curcumin; the combined delivery of both the thymidine kinase gene and curcumin had higher therapeutic effects on glioblastoma than either treatment alone.

\section{Targeting angiogenesis}

Uncontrolled and rapid growth of tumor cells leads to hypoxia and subsequent secretion of cellular angiogenesis signals such as angiopoietins, IL-8, fibroblast growth factor-2, or vascular endothelial growth factor to secure the oxygen and nutrient supply to the tumor cell, a vital process for tumor progres-

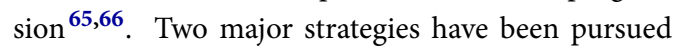
to target glioblastoma cell angiogenesis: upregulating the expression of anti-angiogenic factors and downregulating the expression of pro-angiogenic factors ${ }^{60}$. Sousa et al. ${ }^{67}$ developed an anti-angiogenic monoclonal antibody for glioblastoma multiforme treatment in animal models using bevacizumab-loaded poly(D,L-lactic-co-glycolic acid) nanoparticles to decrease off-target organ toxicity and to circumvent the blood-brain barrier. The monoclonal antibodies were administrated intranasally and showed high brain bioavailability 7 days after administration. The authors reported significant reduction in tumor growth 14 days after administration which resulted from the high anti-angiogenic effect. Some studies have suggested that resistance to anti-angiogenic therapy may 
develop as a result of immune activation ${ }^{68,69}$, specifically as a result of the action of pro-angiogenic M2polarized macrophages. Some researchers have aimed to reprogram or inhibit the M2 phenotype to prevent the development of resistance to anti-angiogenic therapy and have revealed the phenotype to augment strong anti-angiogenic activity in animal models $^{70-72}$. Glioblastomas are characterized by the release of vascular endothelial growth factor, which acts as a regulator and promoter of angiogenesis. Some anti-angiogenic therapies target this regulator or its receptor to inhibit the growth of glioblastoma cells, using monoclonal antibodies against vascular endothelial growth factor in addition to tyrosine kinase inhibitors that target the receptors of vascular endothelial growth factor ${ }^{73,74}$.

\section{Targeting tumor cell-derived exosomes}

Exosomes are a type of extracellular nanovesicle that have an important role in intercellular communications and consist of biological macromolecules such as proteins, DNA, and/or RNA ${ }^{75}$. The exact content of exosomes is dependent of the type of cell from which they are derived and its physiological condition ${ }^{76,77}$. Importantly, many studies have revealed that after internalization by a secondary cell, the released exosomes induced significant phenotypic alterations depending on their content ${ }^{78,79}$. Tumor cells generally secrete higher quantities of exosomes compared with normal cells; these secretions have been reported to play a vital role in promoting tumor progression by inducing malignant transformation of normal cells, cancer-associated fibroblast transformation, tumor escape from the immune system, angiogenesis, and metastasis ${ }^{\mathbf{8 0}}$. Glioblastoma stem cells have been used to release exosomes containing microRNAs to mediate cellular communication; Tian et al. ${ }^{\mathbf{8 1}}$ investigated whether glioblastoma stem cellderived exosomes that contained the microRNA $m i R$ $26 a$ could influence angiogenesis in microvessel endothelial cells in glioblastoma. The authors reported that, in glioblastoma, the tumor suppressor gene PTEN was downregulated while miR-26a was upregulated; this finding was explained by the activation of the PI3K/Akt signaling pathway by $m i R-26 a$, which led to PTEN downregulation. Furthermore, the authors reported that glioblastoma stem cell-derived exosomes containing miR-26a promoted the proliferation, migration, tube formation, and angiogenesis of tumor cells, suggesting that targeting of these exosomes could represent a potential therapeutic approach. Domenis et al. ${ }^{\mathbf{8 2}}$ investigated the properties of immune-mediated tumor-derived exosome release upon activation of toll-like receptor 4 and found that treatment of the tumor influenced tumor-derived exosome composition and boosted its immunosuppressive ability, suggesting that the activation of tolllike receptor 4 supports tumor progression by stimulating the excretion of more effective immunosuppressive exosomes from the cells. This excretion of exosomes allows cancer cells to escape immune surveillance. Hypoxia-mediated stress in glioblastoma multiforme produced qualitative and quantitative changes in exosome content, with significant elevation of protein-lysine 6-oxidase, vascular-derived endothelial factor, and thrombospondin-1, which were all associated with tumor progression, metastasis, and angiogenesis ${ }^{83}$. Kore et al. ${ }^{83}$ demonstrated that hypoxia-related exosomes induced significant differential gene expression in recipient glioblastoma cells, showing a marked upregulation of small nucleolar RNA, C/D box 116-21 transcript, among others, and significant downregulation of voltage-gated potassium channels. Glioblastoma cell-derived exosomes are potential novel therapeutic targets. A significant number of publications address the qualitative and quantitative changes in these nanovesicles and their role in tumor development, and promote the development of preclinical and clinical trials involving these potential new targets ${ }^{84-86}$.

\section{Immunization gene therapy}

Immunization gene therapy is a broad therapeutic approach that involves enhancing the efficacy of the patient's immune system against glioblastoma multiforme cells using chimeric antigen receptor T (CAR$\mathrm{T})$ cell therapy, tumor vaccine therapy, or cytokine gene therapy ${ }^{87}$. In a recent study, Agliardi et al. ${ }^{\mathbf{8 8}}$ used genetically engineered CAR-T cells targeting receptor variant III of the glioblastoma tumor-specific epidermal growth factor in a mouse model and revealed that the engineered cells alone were unable to fully control the established tumors; however, the authors achieved lasting antitumor response when they combined single and locally delivered doses of IL-12. The cytotoxicity of CAR-T cells was significantly enhanced in the presence of IL-12, which also reshaped the tumor microenvironment, decreased the number of regulatory $\mathrm{T}$ cells, and increased the infiltration rate of pro-inflammatory $\mathrm{CD}^{+}{ }^{+} \mathrm{T}$ cells ${ }^{89}$. In a similar study, Tang et al. ${ }^{90}$ transduced a CAR-targeting B7-H3 transmembrane protein into $\mathrm{T}$ cells using a lentivirus. The authors assessed the antitumor effects of the transmembrane protein B7-H3-specific CAR-T cells in vitro and in vivo with primary and glioblastoma cell lines and revealed that $B 7-H 3$ expression 
levels were highly correlated with malignancy grade; in addition, most of the clinical glioma samples were positive for $B 7-H 3$. The study also revealed the association of $B 7-H 3$ with poor survival rates in both low-grade glioma and glioblastoma patients. The results of cytotoxic and ELISA assays confirmed the specific antitumor effects of the engineered CAR-T cells on both cell lines. The authors added that the median survival time of the CAR-T-cell-treated group in the orthotropic glioblastoma models was significantly longer than that of the control group, suggesting promising potential for targeting CAR-T in glioblastoma multiforme treatment.

Tumor vaccination has also been studied in glioblastoma multiforme and involves presenting the tumorspecific antigens to the immune system and triggering an immune response against the antigens ${ }^{91}$. Dendritic cell-based vaccines are one of the novel strategies being tested in recent clinical trials that mediate anticancer immune reactions ${ }^{\mathbf{9 2}}$. A number of dendritic cell-based vaccines for glioblastoma multiforme have been developed and are currently undergoing clinical investigation ${ }^{\mathbf{9 3}}$. Erhart et al. ${ }^{\mathbf{9 4}}$ found that glioblastoma multiforme patients with pre-existing antitumor characteristics seemed to survive longer under dendritic cell-based immunotherapy (Audencel) than patients who lacked these characteristics. The authors reported the inability of Audencel therapy to induce a significant clinical response, but the treatment had a strong effect on the immune system. The pre-vaccination blood count of $\mathrm{CD}^{+} \mathrm{T}$ lymphocytes and the in vitro production capacity of the enzyme-linked immunosorbent spot granzyme B upon exposure to the tumor antigen were significantly correlated with overall patient survival. Dendritic cell-based immunotherapy for glioblastoma multiforme led to significant upregulation of many cytokines promoting Th1 activation, better antitumor response, higher post-vaccination levels of IFN $\gamma$; in addition, the levels of $\mathrm{CD}^{+}$cells in the patients' blood were indicative of better prognosis compared with unvaccinated patients ${ }^{\mathbf{9 4}}$. Other studies proposed immune checkpoint inhibitors for the enhancement of glioblastoma multiforme treat-

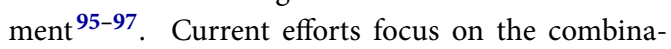
tion of immune checkpoint inhibitors with different glioblastoma treatment modalities such as LAG3 and TIM3 checkpoint inhibitors ${ }^{\mathbf{9 8}, 99}$. Khaddour et al. ${ }^{100}$ reviewed three novel techniques involving immune checkpoint inhibitors, including the administration of adjuvant immune checkpoint inhibitors following surgical resection of glioblastoma, patient selection for treatment with immune checkpoint inhibitors, and combining immune checkpoint inhibitors with other novel therapies (Figure 5). Recently, a variety of receptors, molecules, and pathways have been investigated and have emerged as potential targets for combined immune checkpoint inhibitors, such as TGF$\beta$ inhibitors, CD47 blockade, and colony-stimulating factor-1 ligand inhibitors ${ }^{101}$. Rationally designed immunization gene therapy and combinatorial approaches offer promising treatments for glioblastoma multiforme.

\section{Tumor gene repair}

Abnormal expression of different DNA repair genes is frequently associated with tumorigenesis, although the role of these repair genes in the progression and development of glioblastoma remains unclear ${ }^{102}$. Repairing the damage in tumor genes involves induction of limited, selective alterations to the genetic material of tumor cells, which is consider an advantage of this approach; however, this process contributes to the development of resistance to genotoxic therapies based on tumor-driving cells ${ }^{103}$. Struve et al. ${ }^{104}$ observed significantly elevated expression of several DNA mismatch repair proteins in epidermal growth factor receptor variant III cells and samples from glioblastoma patients; this expression was most pronounced for DNA mismatch repair protein 2 and 6. Epidermal growth factor receptor variant III-specific knockdown reduced mismatch repair protein expression, thereby increasing resistance to the alkylating agent temozolomide and demonstrating that the oncoprotein epidermal growth factor receptor variant III sensitizes a fraction of glioblastoma through the upregulation of DNA mismatch repair proteins. In separate study, Lin et al. ${ }^{105}$ revealed that the inhibition of RNA-binding protein Musashi-1 in glioblastoma multiforme patients radiosensitized tumors, prevented cancer stem cell selection in radiotherapy, and reduced tumor invasion. The authors reported that Musashi-1 enhanced tumor invasion via vascular cell adhesion protein 1 and modulated glioblastoma multiforme radioresistance via hyperactivation of the DNA damage response process through evasion of apoptosis and increased homologous recombination repair. Therefore, knockdown of Musashi-1 induced the accumulation of DNA damage in irradiated glioblastoma multiforme cells and promoted their depletion in vitro. Kun et al. ${ }^{102}$ performed clustering to screen for potentially abnormal DNA repair genes associated with glioblastoma multiforme prognosis and revealed that five DNA repair genes (CDK7, RFC2 DDB2, $R N H 1, F A H$, and $R N H 1)$ were significantly related to 


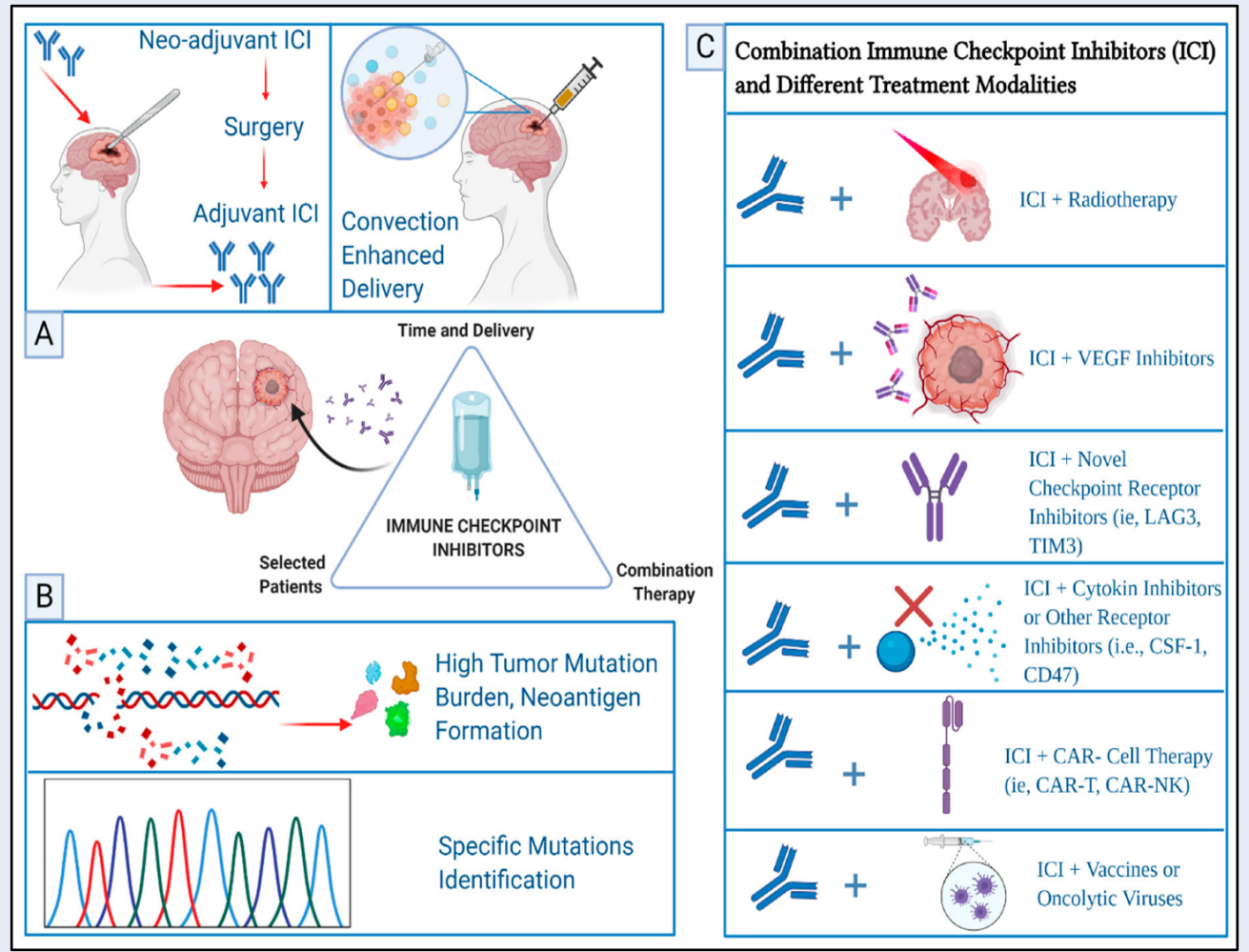

Figure 5: Proposed therapeutic approaches of using immune checkpoint inhibitors for improving glioblastoma multiforme treatment. A: following the surgical resection of glioblastoma with adjuvant immune checkpoint inhibitors administration, B: patient selection for treatment with immune checkpoint inhibitors and C: combination of immune checkpoint inhibitors with other novel therapies. Adapted from Khaddour et al. ${ }^{\mathbf{1 0 0}}$

glioblastoma multiforme prognosis. The prognosis of glioblastoma multiforme can be predicted from the expression of DNA repair genes, which may also represent future therapeutic targets.

\section{Genome editing}

Genome editing-based therapy consists of the modification of whole-body intracellular DNA in a sequence-specific manner via substitution, insertion, deletion, or integration ${ }^{106}$. Maeder et al. ${ }^{107}$ reviewed the most common nucleases used for genome editing, including transcription activator-like effector nucleases, zinc finger nucleases, meganucleases, and the CRISPR/Cas9 system. Among these strategies, CRISPR nuclease Cas9 is the most advanced and versatile system of gene editing technology; it is characterized by highly specific recognition of its target chromosomal DNA and eventual gene disruption ${ }^{108,109}$. This technology opens multiple avenues for the treatment of cancers such as glioblastoma multiforme. Rosenblum et al. ${ }^{108}$ utilized CRISPRencapsulating lipid nanoparticles to promote ther- apeutic gene editing in vitro through the disruption of key glioblastoma multiforme survival genes in murine and human glioblastoma cell lines and in vivo in an aggressive syngeneic glioblastoma mouse model. The authors revealed that a CRISPR lipid nanoparticle-based platform could potentially be developed and utilized in human clinical trials as a new therapeutic modality for glioblastoma multiforme. To test and confirm the role of the CRISPR/Cas9 system in the induction of significant gene mutations in animal genome atlases of glioblastoma multiforme, Chow et al. ${ }^{110}$ analyzed a cloned $m T S G$ library into an adeno-associated virus vector encoding sgRNA that targeted Trp53 and astrocyte-specific GFAP-Cre (frequently mutated in glioblastoma multiforme). The authors reported that, after using the adeno-associated virus vector-based CRISPR/Cas9, many genes were significantly mutated, suggesting that the CRISPR/Cas9 system could play a critical role in glioblastoma multiforme treatment. In another recent investigation, MacLeod et al. ${ }^{111}$ used the CRISPR-Cas9 system in patient-derived glioblastoma 
multiforme stem cells to elucidate the function of the coding genome. The authors identified actionable pathways responsible for the proliferation of cells and revealed the gene-essential circuitry of glioblastoma stemness and growth. The authors also revealed the mechanisms of temozolomide resistance in glioblastoma cells that could lead to combination strategies.

\section{CONCLUSION}

Glioblastoma multiforme is often a fatal disease and most conventional treatment approaches available to patients are only minimally effective. In this review, we discussed the most recent advances in genetic based therapeutic approaches for glioblastoma multiforme. Significant advances have been made in the past decade in developing novel therapeutic approaches using genetic strategies. These advanced techniques have the potential to regulate the expression of glioblastoma multiforme oncogenes without altering the genotype and thus avoid possible genotoxicity. Despite the paucity and expense related to such research, future therapies for chronic and sensitive diseases such as glioblastoma multiforme could involve genetic and/or epigenetic approaches.

\section{ABBREVIATIONS}

CAR-T: chimeric antigen receptor T; CNS: The central nervous system; CRISPR: Clustered regularly interspaced short palindromic repeats; GBM: Glioblastoma multiforme; HSVtk: The herpes simplex virus thymidine kinase; IL: Interleukin; miRNAs: MicroRNAs ; PD-1: Programmed cell death protein 1; siRNA: Small interfering RNA; WHO: World Health Organization

\section{ACKNOWLEDGMENTS}

The authors would like to thank the collaboration between Universiti Teknologi MARA, Shah Alam, Malaysia, Universiti Sains Malaysia, Penang, Malaysia and Hospital Seberang Jaya that made this work possible.

\section{AUTHOR'S CONTRIBUTIONS}

All authors contributed equally to this work. All authors read and approved the final manuscript.

\section{FUNDING}

None.

\section{AVAILABILITY OF DATA AND MATERIALS}

Not applicable.

\section{ETHICS APPROVAL AND CONSENT TO PARTICIPATE}

Not applicable.

\section{CONSENT FOR PUBLICATION}

Not applicable.

\section{COMPETING INTERESTS}

The authors declare that they have no competing interests.

\section{REFERENCES}

1. Agnihotri $S$, Burrell KE, Wolf $A$, Jalali $S$, Hawkins $C$, Rutka JT. Glioblastoma, a brief review of history, molecular genetics, animal models and novel therapeutic strategies. Archivum Immunologiae et Therapiae Experimentalis. 2013;61(1):2541. PMID: 23224339. Available from: 10.1007/s00005-0120203-0.

2. Henley SJ, Ward EM, Scott S, Ma J, Anderson RN, Firth AU. Annual report to the nation on the status of cancer, part I: national cancer statistics. Cancer. 2020;126(10):2225-49. PMID: 32162336. Available from: $10.1002 / \mathrm{cncr} .32802$.

3. Lozada-Delgado EL, Grafals-Ruiz N, Vivas-Mejía PE. RNA interference for glioblastoma therapy: innovation ladder from the bench to clinical trials. Life Sciences. 2017;188:26-36. PMID: 28864225. Available from: 10.1016/j.lfs.2017.08.027.

4. Pottoo FH, Javed MN, Rahman JU, Abu-Izneid T, Khan FA. Targeted delivery of miRNA based therapeuticals in the clinical management of Glioblastoma Multiforme. Seminars in Cancer Biology. 2020;69:391-398. PMID: 32302695. Available from: 10.1016/j.semcancer.2020.04.001.

5. Tsiailanis AD, Renziehausen A, Kiriakidi S, Vrettos El, Markopoulos GS, Sayyad N, et al. Enhancement of glioblastoma multiforme therapy through a novel QuercetinLosartan hybrid. Free Radical Biology \& Medicine. 2020;160:391-402. PMID: 32822744. Available from: 10.1016/j.freeradbiomed.2020.08.007.

6. Kamimura K, Yokoo T, Abe H, Terai S. Gene therapy for liver cancers: current status from basic to clinics. Cancers (Basel). 2019;11(12):1865. PMID: 31769427. Available from: 10.3390/ cancers 11121865.

7. Li J, Chen J, Wang S, Li P, Zheng C, Zhou X. Blockage of transferred exosome-shuttled miR-494 inhibits melanoma growth and metastasis. Journal of Cellular Physiology. 2019;234(9):15763-74. PMID: 30723916. Available from: $10.1002 / j$ cp. 28234 .

8. Izquierdo $M$, Martín $V$, de Felipe $P$, Izquierdo JM, PérezHigueras A, Cortés ML. Human malignant brain tumor response to herpes simplex thymidine kinase (HSVtk)/ganciclovir gene therapy. Gene Therapy. 1996;3(6):491-5. PMID: 8789798.

9. Yahya EB, Alqadhi AM. Recent trends in cancer therapy: $A$ review on the current state of gene delivery. Life Sciences. 2021;269:119087. PMID: 33476633. Available from: 10.1016/ j.lfs.2021.119087.

10. Topper MJ, Vaz M, Marrone KA, Brahmer JR, Baylin SB. The emerging role of epigenetic therapeutics in immunooncology. Nature Reviews Clinical Oncology. 2020;17(2):7590. PMID: 31548600. Available from: 10.1038/s41571-0190266-5.

11. Lu Y, Chan YT, Tan HY, Li S, Wang N, Feng Y. Epigenetic regulation in human cancer: the potential role of epi-drug in cancer therapy. Molecular Cancer. 2020;19(1):79. PMID: 32340605. Available from: 10.1186/s12943-020-01197-3. 
12. Baniebrahimi G, Mir F, Khanmohammadi R. Cancer stem cells and oral cancer: insights into molecular mechanisms and therapeutic approaches. Cancer Cell International. 2020;20(1):113. PMID: 32280305. Available from: 10.1186/ s12935-020-01192-0.

13. Hira VV, Molenaar RJ, Breznik B, Lah T, Aronica E, Noorden CJV. Immunohistochemical Detection of Neural Stem Cells and Glioblastoma Stem Cells in the Subventricular Zone of Glioblastoma Patients. The Journal of Histochemistry and Cytochemistry. 2021;69(5):349-64. PMID: 33596115. Available from: 10.1369/0022155421994679.

14. Wang Y, Zou S, Zhao Z, Liu P, Ke C, Xu S. New insights into small-cell lung cancer development and therapy. Cell Biology International. 2020;44(8):1564-76. PMID: 32281704. Available from: 10.1002/cbin.11359.

15. Yahya EB, Abdulsamad MA, Allaq AA. Recent Advances in the Role of Microorganisms in Cancer Incidence: Mechanisms and Health Precautions. Biomedical Research and Therapy. 2021;8(9):4525-39. Available from: 10.15419/bmrat.v8i9.691.

16. Hanahan D, Coussens LM. Accessories to the crime: functions of cells recruited to the tumor microenvironment. Cancer Cell. 2012;21(3):309-22. PMID: 22439926. Available from: 10.1016/j.ccr.2012.02.022.

17. Ryskalin L, Gaglione A, Limanaqi F, Biagioni F, Familiari $P$, Frati A. The autophagy status of cancer stem cells in gliobastoma multiforme: from cancer promotion to therapeutic strategies. International Journal of Molecular Sciences. 2019;20(15):3824. PMID: 31387280. Available from: 10.3390/ijms20153824.

18. Nakada M, Kita D, Watanabe $T$, Hayashi $Y$, Teng L, Pyko IV. Aberrant signaling pathways in glioma. Cancers (Basel). 2011;3(3):3242-78. PMID: 24212955. Available from: 10. 3390/cancers3033242.

19. Yahya EB, Amirul AA, S AKHP, Olaiya NG, lqbal MO, Jummaat F. Insights into the Role of Biopolymer Aerogel Scaffolds in Tissue Engineering and Regenerative Medicine. Polymers. 2021;13(10):1612. PMID: 34067569. Available from: 10.3390/ polym 13101612 .

20. Hanahan D, Weinberg RA. Hallmarks of cancer: the next generation. cell, 2011. 144(5): p. 646-674. and others, editor; 2011. Available from: 10.1016/j.cell.2011.02.013.

21. Boroughs LK, DeBerardinis RJ. Metabolic pathways promoting cancer cell survival and growth. Nature Cell Biology. 2015;17(4):351-9. PMID: 25774832. Available from: $10.1038 /$ ncb3124.

22. Stone TW, Darlington LG. Microbial carcinogenic toxins and dietary anti-cancer protectants. Cellular and Molecular Life Sciences. 2017;74(14):2627-43. PMID: 28238104. Available from: 10.1007/s00018-017-2487-z.

23. Madhugiri VS, Moiyadi AV, Shetty P, Gupta T, Epari S, Jalal R. An analysis of the factors associated with long term survival in patients with glioblastoma. World Neurosurgery. 2021;149:e758-65. PMID: 33540096. Available from: 10. 1016/j.wneu.2021.01.103.

24. Calabrese $C$, Poppleton $H$, Kocak M, Hogg TL, Fuller C, Hamner B. A perivascular niche for brain tumor stem cells. Cancer Cell. 2007;11(1):69-82. PMID: 17222791. Available from: 10.1016/j.ccr.2006.11.020.

25. Patterson JD, Wongsurawat T, Rodriguez A. A glioblastoma genomics primer for clinicians. Medical Research Archives. 2020;8(2). PMID: 32258388. Available from: $10.18103 / \mathrm{mra}$. v8i2.2034.

26. Llaguno SRA, Parada LF. Cell of origin of glioma: biological and clinical implications. British Journal of Cancer. 2016;115(12):1445-50. PMID: 27832665. Available from: 10.1038/bjc.2016.354.

27. Visvader JE. Cells of origin in cancer. Nature. 2011;469(7330):314-22. PMID: 21248838. Available from: $10.1038 /$ nature09781.

28. Hu J, Zhao Q, Kong LY, Wang J, Yan J, Xia X. Regulation of tumor immune suppression and cancer cell survival by CXCL1/2 elevation in glioblastoma multiforme. Science Ad- vances. 2021;7(5). PMID: 33571109. Available from: 10.1126/ sciadv.abc2511.

29. O'Sullivan D, Sanin DE, Pearce EJ, Pearce EL. Metabolic interventions in the immune response to cancer. Nature Reviews Immunology. 2019;19(5):324-35. PMID: 30820043. Available from: 10.1038/s41577-019-0140-9.

30. Terme M, Ullrich $E$, Aymeric $L$, Meinhardt K, Desbois M, Delahaye N. IL-18 induces PD-1-dependent immunosuppres sion in cancer. Cancer Research. 2011;71(16):5393-9. PMID: 21724589. Available from: 10.1158/0008-5472.CAN-110993.

31. Levine MS, Bakker B, Boeckx B, Moyett J, Lu J, Vitre B, et al. Centrosome amplification is sufficient to promote spontaneous tumorigenesis in mammals. Developmental cell. 2017;40(3):313-322.e5. PMID: 28132847. Available from: 10.1016/j.devcel.2016.12.022.

32. Yahya EB, Jummaat F, Amirul AA, Adnan AS, Olaiya NG, Abdullah CK. A review on revolutionary natural biopolymerbased aerogels for antibacterial delivery. Antibiotics (Basel, Switzerland). 2020;9(10):648. PMID: 32998197. Available from: 10.3390/antibiotics9100648.

33. Bukhari N, Joseph JP, Hussain SS, Khan MA, Wakim MJ, Yahya EB. Prevalence of human papilloma virus sub genotypes following head and neck squamous cell carcinomas in asian continent, a systematic review Article. Asian Pacific journal of cancer prevention. Asian Pacific Journal of Cancer Prevention. 2019;20(11):3269-77. PMID: 31759348. Available from: 10.31557/APJCP.2019.20.11.3269.

34. Lambert AW, Pattabiraman DR, Weinberg RA. Emerging biological principles of metastasis. Cell. 2017;168(4):670-91. PMID: 28187288. Available from: 10.1016/j.cell.2016.11.037.

35. Osisami M, Keller ET. Mechanisms of metastatic tumor dormancy. Journal of Clinical Medicine. 2013;2(3):136-50. PMID: 26237067. Available from: $10.3390 / \mathrm{jcm} 2030136$.

36. Banu A, Gousuddin M, Yahya EB. Green synthesized monodispersed silver nanoparticles' characterization and their efficacy against cancer cells. Biomedical Research and Therapy. 2021;8(8):4476-82. Available from: 10.15419/bmrat. v8i8.686.

37. Chiang CS, Shih IJ, Shueng PW, Kao M, Zhang LW, Chen SF. Tumor cell-targeting radiotherapy in the treatment of glioblastoma multiforme using linear accelerators. Acta Biomaterialia. 2021;125:300-11. PMID: 33609743. Available from: 10.1016/j.actbio.2021.02.019.

38. Gupta N, Prinja S, Patil V, Bahuguna P. Cost-Effectiveness of Temozolamide for Treatment of Glioblastoma Multiforme in India. JCO Glob Oncol. 2021;7(7):108-17. PMID: 33449801. Available from: 10.1200/GO.20.00288.

39. Iqbal MO, Yahya EB, Andleeb S, Ahmed MM, Javaid MU, Shakeel W. In vivo assessment of reversing Cisplatin-Induced nephrotoxicity using Jatropha mollissima crude extract and its potential cytotoxicity. Saudi Journal of Biological Sciences. 2021;28(12):7373-8. PMID: 34867040. Available from: 10.1016/j.sjbs.2021.08.057.

40. Mandl ES, Dirven CM, Buis DR, Postma TJ, Vandertop WP. Repeated surgery for glioblastoma multiforme: only in combination with other salvage therapy. Surgical Neurology. 2008;69(5):506-9. PMID: 18262245. Available from: 10.1016/ j.surneu.2007.03.043.

41. Olivier C, Oliver L, Lalier L, Vallette FM. Drug Resistance in Glioblastoma: The Two Faces of Oxidative Stress. Frontiers in Molecular Biosciences. 2021;7:620677. PMID: 33585565. Available from: 10.3389/fmolb.2020.620677.

42. Lim WH, Choi SH, Yoo RE, Kang KM, Yun TJ, Kim JH. Does radiation therapy increase gadolinium accumulation in the brain?: quantitative analysis of $\mathrm{T} 1$ shortening using $\mathrm{R} 1$ relaxometry in glioblastoma multiforme patients. PLoS One. 2018;13(2):e0192838. PMID: 29444157. Available from: 10. 1371/journal.pone.0192838.

43. Gesundheit B, Ben-David E, Posen Y, Ellis R, Wollmann G, Schneider EM. Effective Treatment of Glioblastoma Multi- 
forme With Oncolytic Virotherapy: A Case-Series. Frontiers in Oncology. 2020;10:702. PMID: 32477944. Available from: $10.3389 /$ fonc. 2020.00702.

44. Wang H, Zhou H, Xu J, Lu Y, Ji X, Yao Y. Different T-cell subsets in glioblastoma multiforme and targeted immunotherapy. Cancer Letters. 2021;496:134-43. PMID: 33022290. Available from: 10.1016/j.canlet.2020.09.028.

45. Chiocca EA, Lang FF, Markert JM. Introduction. Gene and viral therapy for glioblastoma multiforme. Neurosurgical Focus. 2021;50(2):1. PMID: 34333485. Available from: 10.3171/2020. 11.FOCUS20983.

46. Yu $\mathrm{H}$, Zhang $\mathrm{D}$, Lian $\mathrm{M}$. Identification of an epigenetic prognostic signature for patients with lower-grade gliomas. CNS Neuroscience \& Therapeutics. 2021;27(4):470-83. PMID: 33459509. Available from: $10.1111 / \mathrm{cns} .13587$.

47. Gomes SE, Pereira DM, Roma-Rodrigues C, Fernandes AR Borralho PM, Rodrigues CM. Convergence of miR-143 overexpression, oxidative stress and cell death in $\mathrm{HCT} 116$ human colon cancer cells. PLoS One. 2018;13(1):e0191607. PMID: 29360852. Available from: 10.1371/journal.pone.0191607.

48. Yoshida S, Duong C, Oestergaard M, Fazio M, Chen C, Peralta R. MXD3 antisense oligonucleotide with superparamagnetic iron oxide nanoparticles: A new targeted approach for neuroblastoma. Nanomedicine; Nanotechnology, Biology, and Medicine. 2020;24:102127. PMID: 31783139. Available from: 10.1016/j.nano.2019.102127.

49. Gessner I, Yu X, Jüngst C, Klimpel A, Wang L, Fischer T. Selective capture and purification of micrornas and intracellular proteins through antisense-vectorized magnetic nanobeads. Scientific Reports. 2019;9(1):2069. PMID: 30765836. Available from: 10.1038/s41598-019-39575-7.

50. Singh A, Trivedi $P$, Jain NK. Advances in siRNA delivery in cancer therapy. Artificial Cells, Nanomedicine, and Biotechnology. 2018;46(2):274-83. PMID: 28423924. Available from: 10.1080/21691401.2017.1307210

51. Wang J, Cai C, Nie D, Song X, Sun G, Zhi T. FRK suppresses human glioma growth by inhibiting ITGB1/FAK signaling. Biochemical and Biophysical Research Communications. 2019;517(4):588-95. PMID: 31395336. Available from: 10.1016/j.bbrc.2019.07.059.

52. Jian Z, Zhang L, Jin L, Lan W, Zhang W, Gao G. Rab5 regulates the proliferation, migration and invasion of glioma cells via cyclin E. Oncology Letters. 2020;20(2):1055-62. PMID: 32724343. Available from: 10.3892/ol.2020.11660.

53. Franceschi ND, Hamidi H, Alanko J, Sahgal P, Ivaska J. Integrin traffic - the update. Journal of Cell Science. 2015;128(5):83952. PMID: 25663697.

54. Fan $\mathrm{H}$, Xin $\mathrm{T}$, Dong $\mathrm{X}$, Yang $\mathrm{F}$, Zhang $\mathrm{R}$, Feng $\mathrm{S}$. RabGEF1 functions as an oncogene in U251 glioblastoma cells and is involved in regulating AKT and Erk pathways. Experimental and Molecular Pathology. 2021;118:104571. PMID: 33166495. Available from: 10.1016/j.yexmp.2020.104571.

55. Sechi S, Frappaolo A, Karimpour-Ghahnavieh A, Piergentili $R$, Giansanti MG. Oncogenic Roles of GOLPH3 in the Physiopathology of Cancer. International Journal of Molecular Sciences. 2020;21(3):933. PMID: 32023813. Available from: $10.3390 /$ ijms 21030933.

56. Zhan W, Zhang J, Luo Y, Yu R. GOLPH3 silencing inhibits adhesion of glioma U251 cells by regulating ITGB1 degradation under serum starvation. Biochemical and Biophysical Research Communications. 2020;532(2):195-9. PMID: 32859376. Available from: 10.1016/j.bbrc.2020.06.044.

57. Zeng $Y$, Que T, Lin J, Zhan Z, Xu A, Wu Z. Oncogenic ZEB2/miR-637/HMGA1 signaling axis targeting vimentin promotes the malignant phenotype of glioma. Molecular Therapy Nucleic Acids. 2021;23:769-82. PMID: 33614228. Available from: 10.1016/j.omtn.2020.12.029.

58. Safaee S, Fardi M, Hemmat N, Khosravi N, Derakhshani A, Silvestris N. Silencing ZEB2 Induces Apoptosis and Reduces Viability in Glioblastoma Cell Lines. Molecules (Basel, Switzerland). 2021:26(4):901. PMID: 33572092. Available from: 10.3390/molecules26040901.
59. Qiu XY, Hu DX, Chen WQ, Chen RQ, Qian SR, Li CY. PD-L1 confers glioblastoma multiforme malignancy via Ras binding and Ras/Erk/EMT activation. Biochimica et Biophysica Acta Molecular Basis of Disease. 2018;1864(5):1754-69. PMID: 29510196. Available from: 10.1016/j.bbadis.2018.03.002.

60. Sun W, Shi Q, Zhang H, Yang K, Ke Y, Wang Y. Advances in the techniques and methodologies of cancer gene therapy. Discovery Medicine. 2019;27(146):45-55. PMID: 30721651.

61. Navarro SA, Carrillo E, Griñán-Lisón C, Martín A, Perán M, Marchal JA. Cancer suicide gene therapy: a patent review. Expert Opinion on Therapeutic Patents. 2016;26(9):1095-104. PMID: 27424657. Available from: 10.1080/13543776.2016. 1211640.

62. Li M, Sun S, Dangelmajer S, Zhang Q, Wang J, Hu F, et al. Exploiting tumor-intrinsic signals to induce mesenchymal stem cell-mediated suicide gene therapy to fight malignant glioma. Stem Cell Research and Therapy. 2019;10:88. PMID: 30867058. Available from: 10.1186/s13287-019-1194-0.

63. Westphal M, Ylä-Herttuala S, Martin J, Warnke P, Menei P, Eckland $D$, et al. Adenovirus-mediated gene therapy with sitimagene ceradenovec followed by intravenous ganciclovir for patients with operable high-grade glioma (ASPECT): a randomised, open-label, phase 3 trial. The Lancet Oncology. 2013;14(9):823-33. PMID: 23850491. Available from: 10. 1016/S1470-2045(13)70274-2.

64. Park JH, Han J, Lee M. Thymidine kinase gene delivery using curcumin loaded peptide micelles as a combination therapy for glioblastoma. Pharmaceutical Research. 2015;32(2):52837. PMID: 25158647. Available from: 10.1007/s11095-014$1482-4$.

65. Palma MD, Biziato D, Petrova TV. Microenvironmental regulation of tumour angiogenesis. Nature Reviews Cancer. 2017;17(8):457-74. PMID: 28706266. Available from: 10. 1038/nrc.2017.51.

66. Lugano R, Ramachandran M, Dimberg A. Tumor angiogenesis: causes, consequences, challenges and opportunities. Cellular and Molecular Life Sciences. 2020;77(9):174570. PMID: 31690961. Available from: 10.1007/s00018-01903351-7.

67. Sousa F, Dhaliwal HK, Gattacceca F, Sarmento B, Amiji MM. Enhanced anti-angiogenic effects of bevacizumab in glioblastoma treatment upon intranasal administration in polymeric nanoparticles. Journal of Controlled Release. 2019;309:37-47. PMID: 31344424. Available from: 10.1016/j. jconrel.2019.07.033.

68. Chung AS, Wu X, Zhuang G, Ngu H, Kasman I, Zhang J. An interleukin-17-mediated paracrine network promotes tumor resistance to anti-angiogenic therapy. Nature Medicine. 2013;19(9):1114-23. PMID: 23913124. Available from: 10. $1038 / \mathrm{nm} .3291$.

69. Shojaei F, Wu X, Qu X, Kowanetz M, Yu L, Tan M. G-CSFinitiated myeloid cell mobilization and angiogenesis mediate tumor refractoriness to anti-VEGF therapy in mouse models. Proceedings of the National Academy of Sciences of the United States of America. 2009;106(16):6742-7. PMID: 19346489. Available from: 10.1073 /pnas. 0902280106 .

70. Kloepper J, Riedemann L, Amoozgar Z, Seano G, Susek K, Yu V. Ang-2/NEGF bispecific antibody reprograms macrophages and resident microglia to anti-tumor phenotype and prolongs glioblastoma survival. Proceedings of the National Academy of Sciences of the United States of America. 2016;113(16):4476-81. PMID: 27044098. Available from: $10.1073 /$ pnas. 1525360113 .

71. Tripathi C, Tewari BN, Kanchan RK, Baghel KS, Nautiyal N, Shrivastava R. Macrophages are recruited to hypoxic tumor areas and acquire a pro-angiogenic M2-polarized phenotype via hypoxic cancer cell derived cytokines Oncostatin M and Eotaxin. Oncotarget. 2014;5(14):5350-68. PMID: 25051364. Available from: 10.18632/oncotarget.2110.

72. Scholz A, Harter PN, Cremer S, Yalcin BH, Gurnik S, Yamaji M. Endothelial cell-derived angiopoietin-2 is a therapeutic tar- 
get in treatment-naive and bevacizumab-resistant glioblastoma. EMBO Molecular Medicine. 2016;8(1):39-57. PMID: 26666269. Available from: 10.15252/emmm.201505505.

73. Arbab AS, Ali MM. Glioblastoma: Targeting Angiogenesis and Tyrosine Kinase Pathways. Novel approaches in cancer study. 2020;4(5):398-401. PMID: 32924014.

74. Krcek R, Matschke V, Theis V, Adamietz IA, Bühler $H$, Theiss $C$. Vascular endothelial growth factor, irradiation, and axitinib have diverse effects on motility and proliferation of glioblastoma multiforme cells. Frontiers in Oncology. 2017;7:182. PMID: 28879167. Available from: 10.3389/fonc.2017.00182.

75. Ahmadi M, Rezaie J. Tumor cells derived-exosomes as angiogenenic agents: possible therapeutic implications. Journal of Translational Medicine. 2020;18(1):249. PMID: 32571337. Available from: 10.1186/s12967-020-02426-5.

76. Aslan C, Maralbashi S, Salari F, Kahroba H, Sigaroodi F, Kazemi T. Tumor-derived exosomes: implication in angiogenesis and antiangiogenesis cancer therapy. Journal of Cellular Physiology. 2019;234(10):16885-903. PMID: 30793767. Available from: $10.1002 /$ jcp.28374.

77. Almashgab AM, Yahya EB, Banu A. The Cytotoxicity Effects of Outer Membrane Vesicles Isolated from Hospital and Laboratory Strains of Pseudomonas Aeruginosa on $\mathrm{Hu}-$ man Keratinocyte Cell Line. Malaysian Journal of Science. 2020;39(3):45-53. Available from: 10.22452/mjs.vol39no3.3.

78. Shimada Y, Minna JD. Exosome mediated phenotypic changes in lung cancer pathophysiology. Translational Cancer Research. 2017;6(S6):1040-2. PMID: 30613485. Available from: 10.21037/tcr.2017.07.09.

79. Roma-Rodrigues $C$, Pereira F, de Matos APA, Fernandes $M$ Baptista PV, Fernandes AR. Smuggling gold nanoparticles across cell types - A new role for exosomes in gene silencing. Nanomedicine; Nanotechnology, Biology, and Medicine. 2017;13(4):1389-98. PMID: 28137659. Available from: 10.1016/j.nano.2017.01.013.

80. Roma-Rodrigues C, Fernandes AR, Baptista PV. Exosome in tumour microenvironment: overview of the crosstalk between normal and cancer cells. BioMed research international. 2014;2014:179486. Available from: 10.1155/2014/ 179486.

81. Tian X, Shen H, Li Z, Wang T, Wang S. Tumor-derived exosomes, myeloid-derived suppressor cells, and tumor microenvironment. Journal of Hematology \& Oncology. 2019;12(1):84. PMID: 31438991. Available from: 10.1186/ s13045-019-0772-z.

82. Domenis R, Cifù $A$, Marinò $D$, Fabris $M$, Niazi KR, Soon-Shiong P. Toll-Like receptor- 4 activation boosts the immunosuppressive properties of tumor cells-derived exosomes. Scientific Reports. 2019;9(1):8457. PMID: 31186484. Available from: 10.1038/s41598-019-44949-y.

83. Kore RA, Edmondson JL, Jenkins SV, Jamshidi-Parsian A Dings RP, Reyna NS. Hypoxia-derived exosomes induce putative altered pathways in biosynthesis and ion regulatory channels in glioblastoma cells. Biochemistry and Biophysics Reports. 2018;14:104-13. PMID: 29872742. Available from: 10.1016/j.bbrep.2018.03.008.

84. Zhang G, Zhang $Y$, Cheng $S$, Wu Z, Liu F, Zhang J. CD133 positive U87 glioblastoma cells-derived exosomal microRNAs in hypoxia- versus normoxia-microenviroment. Journal of Neuro-Oncology. 2017;135(1):37-46. PMID: 28948499. Available from: 10.1007/s11060-017-2566-x.

85. Guescini M, Genedani S, Stocchi V, Agnati LF. Astrocytes and Glioblastoma cells release exosomes carrying mtDNA. Journal of Neural Transmission (Vienna, Austria). 2010;117(1):1-4. PMID: 19680595. Available from: 10.1007/s00702-009-02888.

86. Salarpour $S$, Forootanfar $H$, Pournamdari $M$, AhmadiZeidabadi M, Esmaeeli M, Pardakhty A. Paclitaxel incorporated exosomes derived from glioblastoma cells: comparative study of two loading techniques. Daru : Journal of Faculty of Pharmacy, Tehran University of Medical Sciences. 2019;27(2):533-9. PMID: 31317441. Available from: 10.1007/s40199-019-00280-5.

87. D'Ippolito E, Schober K, Nauerth M, Busch DH. T cell engineering for adoptive $\mathrm{T}$ cell therapy: safety and receptor avidity. Cancer Immunology, Immunotherapy. 2019;68(10):1701-12. PMID: 31542797. Available from: 10.1007/s00262-019-02395-9.

88. Agliardi G, Liuzzi AR, Hotblack A, Feo DD, Núñez N, Stowe CL. Intratumoral IL-12 delivery empowers CAR-T cell immunotherapy in a pre-clinical model of glioblastoma. Nature Communications. 2021;12(1):444. PMID: 33469002. Available from: 10.1038/s41467-020-20599-x.

89. Yang Z, Bobbins M, Choi H, Stefanson O, Yang J, Magallanes $\mathrm{K}$, et al. Contextual secretion of nanoscale interleukin (IL)12 by CAR T cells for the treatment of cancer. Journal for ImmunoTherapy of Cancer. 2020;2020(8). Available from: 10.1136/jitc-2020-SITC2020.0765.

90. Tang X, Zhao S, Zhang Y, Wang Y, Zhang Z, Yang M. B7-H3 as a novel CAR-T therapeutic target for glioblastoma. Molecular Therapy Oncolytics. 2019;14:279-87. PMID: 31485480. Available from: 10.1016/j.omto.2019.07.002.

91. Londhe VY, Date V. Personalized neoantigen vaccines: a glimmer of hope for glioblastoma. Expert Review of Vaccines. 2020;19(5):407-17. PMID: 32238056. Available from: 10.1080/14760584.2020.1750376.

92. Silver DJ, Sinyuk M, Vogelbaum MA, Ahluwalia MS, Lathia JD. The intersection of cancer, cancer stem cells, and the immune system: therapeutic opportunities. Neuro-Oncology. 2016;18(2):153-9. PMID: 26264894. Available from: 10.1093/ neuonc/nov157.

93. Lim M, Xia Y, Bettegowda C, Weller M. Current state of immunotherapy for glioblastoma. Nature Reviews Clinical Oncology. 2018;15(7):422-42. PMID: 29643471. Available from: 10.1038/s41571-018-0003-5.

94. Erhart F, Buchroithner J, Reitermaier R, Fischhuber K, Klingenbrunner S, Sloma I. Immunological analysis of phase II glioblastoma dendritic cell vaccine (Audencel) trial: immune system characteristics influence outcome and Audencel upregulates Th1-related immunovariables. Acta Neuropathologica Communications. 2018;6(1):135. PMID: 30518425. Available from: 10.1186/s40478-018-0621-2.

95. Cloughesy TF, Mochizuki AY, Orpilla JR, Hugo W, Lee $\mathrm{AH}_{\text {, }}$ Davidson TB. Neoadjuvant anti-PD-1 immunotherapy promotes a survival benefit with intratumoral and systemic immune responses in recurrent glioblastoma. Nature Medicine. 2019;25(3):477-86. PMID: 30742122. Available from: 10. 1038/s41591-018-0337-7.

96. Schalper KA, Rodriguez-Ruiz ME, Diez-Valle R, López-Janeiro A, Porciuncula A, Idoate MA. Neoadjuvant nivolumab modifies the tumor immune microenvironment in resectable glioblastoma. Nature Medicine. 2019;25(3):470-6. PMID: 30742120. Available from: 10.1038/s41591-018-0339-5.

97. Zhao J, Chen AX, Gartrell RD, Silverman AM, Aparicio L, Chu T. Immune and genomic correlates of response to antiPD-1 immunotherapy in glioblastoma. Nature Medicine. 2019;25(3):462-9. PMID: 30742119. Available from: 10.1038/ s41591-019-0349-y.

98. Kim JE, Patel MA, Mangraviti A, Kim ES, Theodros D, Velarde E. Combination therapy with anti-PD-1, anti-TIM-3, and focal radiation results in regression of murine gliomas. Clinical Cancer Research. 2017;23(1):124-36. PMID: 27358487. Available from: 10.1158/1078-0432.CCR-15-1535.

99. Harris-Bookman $S$, Mathios D, Martin AM, Xia Y, Kim E, $\mathrm{Xu} \mathrm{H}$. Expression of LAG-3 and efficacy of combination treatment with anti-LAG-3 and anti-PD-1 monoclonal antibodies in glioblastoma. International Journal of Cancer. 2018;143(12):3201-8. PMID: 30248181. Available from: 10.1002/ijc.31661.

100. Khaddour K, Johanns TM, Ansstas G. The Landscape of Novel Therapeutics and Challenges in Glioblastoma Multiforme: Contemporary State and Future Directions. Pharmaceuticals (Basel, Switzerland). 2020;13(11):389. PMID: 33202642. Avail- 
able from: $10.3390 / \mathrm{ph} 13110389$.

101. Weenink B, French PJ, Smitt PAS, Debets R, Geurts M. Immunotherapy in glioblastoma: current shortcomings and future perspectives. Cancers (Basel). 2020;12(3):751. PMID: 32235752. Available from: $10.3390 /$ cancers 12030751

102. Kun $S$, Duan $Q$, Liu G, Lu JM. Prognostic value of DNA repair genes based on stratification of glioblastomas. Oncotarget. 2017;8(35):58222-30. PMID: 28938550. Available from: 10. 18632/oncotarget.17452.

103. Annovazzi L, Mellai M, Schiffer D. Chemotherapeutic drugs: DNA damage and repair in glioblastoma. Cancers (Basel). 2017;9(6):57. PMID: 28587121. Available from: 10.3390/ cancers9060057.

104. Struve N, Binder ZA, Stead LF, Brend T, Bagley SJ, Faulkner C. EGFRvIll upregulates DNA mismatch repair resulting in increased temozolomide sensitivity of MGMT promoter methylated glioblastoma. Oncogene. 2020;39(15):3041-55. PMID: 32066879 . Available from: 10.1038/s41388-020-12085.

105. Lin JC, Tsai JT, Chao TY, Ma HI, Chien CS, Liu WH. MSI1 associates glioblastoma radioresistance via homologous recombination repair, tumor invasion and cancer stem-like cell properties. Radiotherapy and Oncology : Journal of the European Society for Therapeutic Radiology and Oncology. 2018;129(2):352-63. PMID: 30322656. Available from: 10 . 1016/j.radonc.2018.09.014.
106. Yeh CD, Richardson CD, Corn JE. Advances in genome editing through control of DNA repair pathways. Nature Cell Biology. 2019;21(12):1468-78. PMID: 31792376. Available from: 10. 1038/s41556-019-0425-z.

107. Maeder ML, Gersbach CA. Genome-editing technologies for gene and cell therapy. Molecular Therapy. 2016;24(3):43046. PMID: 26755333. Available from: 10.1038/mt.2016.10.

108. Rosenblum D, Gutkin A, Peer D. SCIDOT-40. Therapeutic genome editing as a novel treatment for GBM. NeuroOncology. 2019;21:vi280. Available from: 10.1093/neuonc/ noz175.1176.

109. van der Weyden L, Jonkers J, Adams DJ. The use of CRISPR/Cas9-based gene editing strategies to explore cancer gene function in mice. Current Opinion in Genetics \& Development. 2021;66:57-62. PMID: 33429291. Available from: 10.1016/j.gde.2020.12.005.

110. Chow RD, Guzman CD, Wang G, Schmidt F, Youngblood MW Ye L. AAV-mediated direct in vivo CRISPR screen identifies functional suppressors in glioblastoma. Nature Neuroscience. 2017;20(10):1329-41. PMID: 28805815. Available from: $10.1038 / \mathrm{nn} .4620$.

111. MacLeod G, Bozek DA, Rajakulendran N, Monteiro V, Ahmadi $M$, Steinhart Z, et al. Genome-wide CRISPR-Cas9 screens expose genetic vulnerabilities and mechanisms of temozolomide sensitivity in glioblastoma stem cells. Cell reports. 2019;27(3):971-986. e9. PMID: 30995489. Available from 10.1016/j.celrep.2019.03.047. 
Ready to submit your manuscript? Choose Biomedpress and benefit from:

- Fast, convenient online submission

- Through peer-review by experienced researchers

- Rapid publication on acceptance

- Free of charge (without publication fees)

Learn more http://www.biomedpress.org/journals/
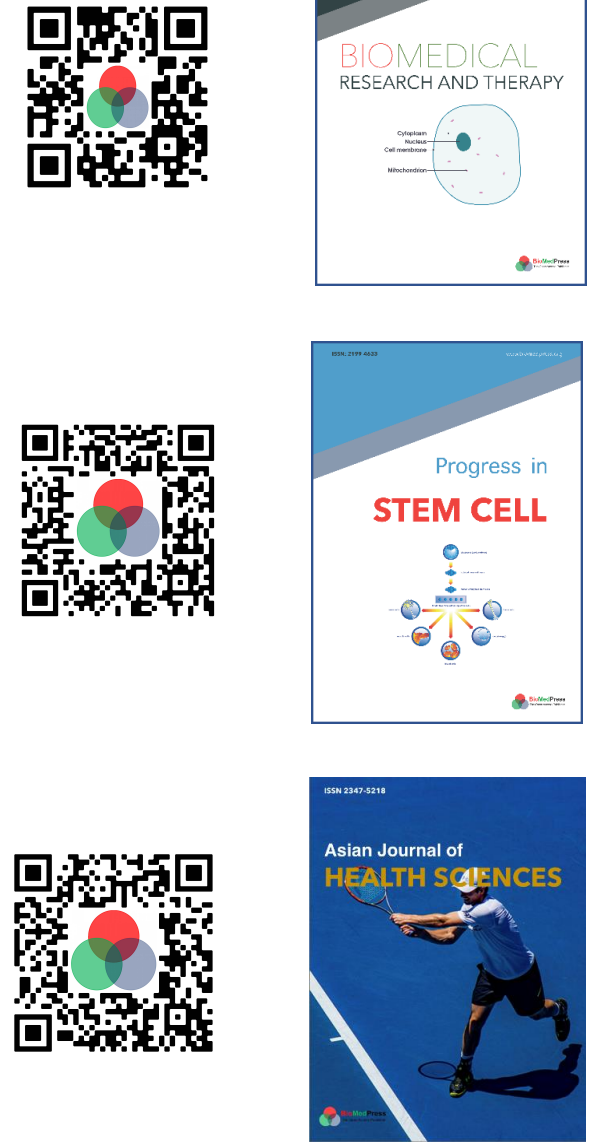

Asian Journal of Health Sciences

ISSN: 2347-5218

Indexed: Google Scholar

Acceptance Rate (2020): 72.89\%

Article Publishing Charge: Free

Submission to first editorial decision: 16.5 days

Biotechnological Research

ISSN: 2395-6763

Indexed: Google Scholar

Acceptance Rate (2020): $67.02 \%$

Article Publishing Charge: Free

Submission to first editorial decision: 28.5 days 